\title{
Antecedents and consequences of organizational commitment, entrenchment, and consent
}

Gean Carlos TOMazzon ${ }^{1}$

VÂNIA Medianeira Flores COSTA ${ }^{2}$

${ }^{1}$ Universidade Federal do Rio Grande do Sul (UfrgS) / Programa de Pós-Graduação em Administração, Porto Alegre - RS, Brazil

${ }^{2}$ Universidade Federal de SANTA MARIA (UFSM) / Departamento de CIÊNCIAS AdMINISTRATIVAS, SANTA MARIA - RS, BRAZIL

\begin{abstract}
This study aims to develop a model that analyzes the influence of organizational values as antecedent variables of the individuals' commitment, entrenchment and consent with the organization, and work performance as the consequent variable of this relationship between individuals and organizations. Descriptive and conclusive research was carried out using a quantitative and qualitative approach. The research was structured in two phases. In the first phase, the data were collected from the application of a closed questionnaire. For the quantitative data, the analysis was operationalized by means of the modeling technique of structural equations. In the second phase, data were collected through semi-structured interviews. The analysis of the qualitative data was carried out using the technique of content analysis. The results reveal that certain values shared by the organization are determinants of the type of linkages that the individual develops with the organization, with different values influencing different linkages. Also, as a consequence, the type of organizational link established influences the performance of the individual at work.
\end{abstract}

Keywords: Organizational commitment. Organizational entrenchment. Organizational consent. Organizational values. Work performance.

\section{Vinculos organizacionais de comprometimento, entrincheiramento e consentimento: explorando seus antecedentes e consequentes}

\section{Resumo}

Este trabalho tem por objetivo desenvolver um modelo que analise as influências dos valores organizacionais nos vínculos de comprometimento, entrincheiramento e consentimento do indivíduo com a organização, como variáveis antecedentes, e o desempenho no trabalho, como variável consequente. Para alcançar o objetivo traçado, realizou-se uma pesquisa de natureza descritiva e explicativa, com abordagem de métodos mistos - quantitativos e qualitativos. A pesquisa foi estruturada em duas fases. Na primeira fase, os dados foram coletados a partir da aplicação de um questionário de pesquisa fechado. Para os dados quantitativos, a análise foi operacionalizada por meio da técnica de modelagem de equações estruturais. Na segunda fase, os dados foram coletados por meio de entrevistas semiestruturadas. A análise dos dados qualitativos foi realizada por meio da técnica de análise de conteúdo. Os resultados revelam que determinados valores compartilhados pela organização são determinantes do tipo de vínculos que o indivíduo estabelece com a organização, sendo que valores distintos influenciam vínculos distintos. Ademais, como consequente, o tipo de vínculo organizacional estabelecido influencia o desempenho do indivíduo no trabalho.

Palavras-chave: Comprometimento organizacional. Entrincheiramento organizacional. Consentimento organizacional. Valores organizacionais. Desempenho no trabalho.

\section{Vínculos organizacionales de compromiso, atrincheramiento y consentimiento: explorando sus antecedentes y consecuentes}

\section{Resumen}

Este trabajo tiene por objetivo desarrollar un modelo que analice las influencias de los valores organizacionales en los vínculos de compromiso, atrincheramiento y consentimiento del individuo con la organización como variables antecedentes y el desempeño en el trabajo como variable consecuente. Para alcanzar el objetivo trazado se realizó una investigación de naturaleza descriptiva y explicativa, con el empleo de métodos mixtos - cuantitativos y cualitativos. La investigación fue estructurada en dos fases. En la primera fase, los datos fueron recolectados a partir de un cuestionario de encuesta cerrado. Para los datos cuantitativos, el análisis fue realizado por medio de la técnica de modelado de ecuaciones estructurales. En la segunda fase, los datos fueron recolectados por medio de la realización de entrevistas semiestructuradas. El análisis de los datos cualitativos se realizó con el empleo de la técnica de análisis de contenido. Los resultados revelan que ciertos valores compartidos por la organización son determinantes del tipo de vínculos que el individuo desarrolla con la organización y valores distintos influencian vínculos distintos. Aún, como consecuente, el tipo de vínculo organizacional establecido influye en el desempeño del individuo en el trabajo.

Palabras clave: Compromiso organizacional. Atrincheramiento organizacional. Consentimiento organizacional. Valores organizacionales. Rendimiento en el trabajo.

Article submitted on June 01, 2018 and accepted for publication on September 24, 2018.

[Translated version] Note: All quotes in English translated by this article's translator.

DOI: http://dx.doi.org/10.1590/1679-395175056x 


\section{INTRODUCTION}

The development of the theoretical perspectives on the relationships established between the individual and the organization has revealed other types of linkages, different from commitment. Entrenchment and consent are among these types of linkage, and they have contributed to limit 'commitment' to its affective nature (BASTOS and AGUIAR, 2015; PINHO, BASTOS and ROWE, 2015a). Klein, Molloy and Brinsfield (2012) consider commitment as a particular type of psychological bond and recognize that other linkages are important and, in certain contexts, more suitable. For the authors, further studies are necessary to understand other types of psychological bonds, as well as to understand and predict which is the most desirable type of connection in a given context. When understanding that there are different linkages, it is important to expand the knowledge about the antecedents and consequences of each one of them. Therefore, it is essential first to comprehend how these connections differ from each other and produce different results for the organization.

Organizational values can predict the different linkages between the individual and the organization, and are, therefore, antecedent factors of these ties. Tamayo (2005) understands that values become operational as prioritized principles and goals that influence behavior. The author recognizes values as a basis capable of guiding the lives of individuals, either directly or indirectly, mirroring their actions. In this way, different principles and goals the organization prioritizes can predict different types - commitment, entrenchment, and consent - and levels of relationships established by the individual with the organization. Therefore, analyzing linkages between individual and organization means considering the factors that can explain their triggers, such as organizational values, seeking to understand the development of affective (commitment), instrumental (entrenchment), and normative (consent) ties.

The worker who internalizes the organization's values identifies with its objectives. They engage with the work roles and want to continue working for the organization. These characteristics indicate that the individual developed a psychological connection, a bond between the worker and the organization (MOWDAY, PORTER and STEERS, 1982; PINHO, 2009). Considering that commitment, entrenchment, and consent are different linkages, it is possible that different organizational values can explain them. The dynamic characteristic attributed to the notion of commitment presupposes the sharing of values that emphasize independent thoughts and actions that favor the process of change, challenges, and variety in work, creativity, innovation, and work collaboratively. The entrenchment, as an instrumental linkage of the permanence of the individual based on necessity, can be stimulated by values related to the protection of stability, as well as by values that prioritize the worker's individual interests. Consent, such as a passive linkage that presupposes the automatic fulfillment of orders, can be stimulated by values that prioritize autocratic, rigid, and inflexible structures, where attitudes of compliance with orders and norms prevail, without opening for the worker's innovation and autonomy.

Regarding the consequences of the individual's linkages with the organization, Medeiros and Albuquerque (2005, p. 27, our translation) state that the studies on commitment are based on a common basic premise that guides the research: "a high level of commitment leads companies to achieve their organizational goals and consequently show better performance." For Scheible and Bastos (2013), despite the studies that show the importance of commitment in organizational results, there are still many questions challenging researchers and managers. The need to deepen the influence of the linkages between the individual and the organization on workers' performance is reinforced with the emergence of new approaches that restrict commitment to its affective basis and develop new constructs - entrenchment and consent.

Against this backdrop, this article aims to develop a model that analyzes the influences of organizational values on commitment, entrenchment, and consent of the individual concerning the organization, as antecedent variables, and work performance, as a consequent variable.

\section{THEORETICAL FRAMEWORK}

\section{Organizational commitment, entrenchment, and consent}

Commitment represents a central construct in the field of study of organizational behavior and has gained relevance now more than ever (KLEIN, MOLLOY and BRINSFIELD, 2012). Despite the dynamic nature of work relationships, organizations need a committed workforce and most people want to be committed to something (KLEIN, 2016). Commitment, considering career, team, the organization, and other elements related to the workplace, is still an important determinant of the results 
of organizations. At the organizational level, having a committed workforce is associated with higher levels of performance, profit margins, and customer satisfaction (CAMERON, BRIGHT and CAZA, 2004; HARTER, SCHMIDT, ASPLUND et al., 2010; HEAVEY, HOLWERDA and HAUSKNECHT, 2013). Regarding the individual benefits of commitment, Gao-Urhahn, Biemann and Jaros (2016) found that committed workers are more likely to obtain higher income.

Organizational commitment is often defined as a connection of the individual with the organization (MAIA, BASTOS and SOLINGER, 2016). Meyer and Allen (1991) propose a three-component conceptualization of this connection. The first component is a desire and represents an affective commitment. In this case, the individual wants to remain in the organization because of feelings of affection. This component emphasizes the emotional nature of the linkage between a person and the organization. The second component is obligation. The individual feels morally obliged to remain, and the authors consider this a normative commitment. The third component refers to the cost associated with breaking the connection. The employee perceives their specific investment in the relationship with the organization and has no alternative to move elsewhere, leading to what the authors call continuance or instrumental commitment (MEYER and ALLEN, 1991).

Although Meyer and Allen's conceptualization model is dominant in Brazilian and international research, this structure in the three-component model is far from representing a consensus in the field, particularly normative and continuance commitment (BALSAN, COSTA, BASTOS et al., 2017). The inconsistency of the structure and the theoretical and empirical expansion on the theme consolidate the argument that affective commitment is very different from the other two (BASTOS and AGUIAR, 2015; PINHO, BASTO and ROWE, 2015b). Thus, studies discuss the dimension of the commitment by including the notions of the permanence of the employee based on a need, an obligation, or to avoid the loss of investments or personal costs related to leaving or having limited work options. Some authors, therefore, argue that these phenomena cannot be called 'commitment,' and two other constructs emerge, organizational entrenchment (RODRIGUES and BASTOS, 2015) and organizational consent (SILVA and BASTOS, 2015).

This study explores the complexity of the linkages employee-organization, assuming that commitment is a bond of affective nature (MOWDAY, PORTER and STEERS, 1982), which is conceptually less controversial. It is also a notion of commitment more strongly associated with desirable behaviors at work (PINHO, BASTOS and ROWE, 2015a). In addition, considering commitment as a bond related to affection is consistent with the proposal of measuring the construct developed by Bastos and Aguiar (2015). Continuance (or instrumental) and normative linkages may be explored as phenomena distinct from commitment, called entrenchment and consent, respectively.

The concept of entrenchment was initially discussed in the field of career studies by Carson and Bedeian (1994). It was introduced by the authors to differentiate 'commitment' of the individual's tendency to continue in the same occupation due to investments made in the career, loss of emotional costs when changing occupation, and due to limited perception of alternative paths outside the current professional field. Based on research about career entrenchment, Rodrigues and Bastos (2012) adapted the concept to the organizational context. The authors built on the same theoretical framework used to study instrumental commitment, grounded in the notion of material exchanges (BECKER, 1960), embedded in the entrenchment construct.

Organizational entrenchment is defined by Rodrigues and Bastos (2015) as a tendency for the individual to remain in the organization to avoid potential losses, due to the costs associated with leaving the institution, and the perceived limitations regarding alternatives in the labor market. In addition, the essence of the individual's entrenchment with the organization is the idea of being stuck for not being able to visualize an alternative able to preserve the employee's integrity according to their needs and expectations. This is the definition put forward in this article. It is a definition operated according to the construct, which integrates three analytical dimensions: adjustment to social position, impersonal bureaucratic arrangements, and limitations of alternatives (RODRIGUES and BASTOS, 2015).

Adjustments to social position refer to the individual's investments to guarantee the necessary conditions during an adaptation period (training to perform specific activities, for example). This would contribute to their adjustment and recognition in the organization, and it is an investment that would be lost if the employee leaves. Impersonal bureaucratic arrangements comprise financial stability and benefits that would be lost if the individual left the organization, such as paid holidays and 
others. The limitation of alternatives refers to the perception of restrictions in the labor market and the lack of alternatives if the individual left the organization (RODRIGUES and BASTOS, 2015).

Organizational consent linkage presupposes that the worker consents to the organizational demands, fully complies with the established orders, and does not consider themselves responsible for any consequences, mainly negative, that may arise from their actions (SILVA and BASTOS, 2015). The construct of consent has its technical foundations in the literature of social psychology and sociology, characterized by the link between individual and organization established from a perspective that rejects affection and psychological elements. It emphasizes the control and authority relationships that induce the worker to obey or fulfill the expected subordinate role (PINHO, BASTOS and ROWE, 2015a).

Silva and Bastos (2015) have been studying this new construct, proposing a new measurement scale proposal. The concept of organizational consent guiding this research is based on the definition proposed by Silva and Bastos (2015), which delimits consent to the notion of the individual's tendency to behave according to the orders established by their superior in the organization hierarchy, who represents the institution, understanding that this is their role at work.

\section{Organizational values}

In organizations, values involve hierarchically systematic principles or beliefs related to organizational goals and desirable behaviors (PAIVA and DUTRA, 2017). According to Tamayo and Gondim (1996, p. 63, our translation) values are "principles or beliefs hierarchically organized that refer to types of structure or desirable behavioral models guiding the company's life and serving to the individual, collective, or mixed interests."

Analyzing organizational values from the perspective of the organization's members - which identifies the existing and practiced values -, Oliveira and Tamayo (2004) adopted Schwartz's (1992) personal values structure and empirically tested the hypothesis that the same motivations support both personal value systems and the organizational sphere.

According to Schwartz's (1992) theory, motivational types of values are organized in two dimensions. The dimension openness to change versus conservation refers to values related to independent thoughts and action (stimulation, self-direction, and hedonism) regarding 'change' and values that emphasize self-restraint, preservation of traditional practices, and protection of stability - security, compliance, and tradition. The second dimension, self-enhancement versus self-transcendence, opposes relative values that favor the interests of the individual, even at the expense of others - power, achievement, and hedonism - as opposed to the concern for the well-being of others and nature - universalism and benevolence.

In their quest to transpose the theoretical perspective from individual to organizational values, Oliveira and Tamayo (2004) propose the 'inventory of organizational values.' Tamayo (2005) builds on the previous study observing that personal values express the individual's goals, whereas the organizational values refer to the organization's objectives. Both are characterized as principles that guide the lives of people and groups, consisting of motivational, cognitive, hierarchical, and social components.

Box 1 shows the correspondence between individual values, according to Schwartz (1992), and organizational values, as proposed by Oliveira and Tamayo (2004). 


\section{Box 1}

\section{Correspondence between individual and organizational values}

\begin{tabular}{|c|c|c|}
\hline $\begin{array}{l}\text { Organizational } \\
\text { values }\end{array}$ & Correspondence & Organizational goals \\
\hline Autonomy & $\begin{array}{l}\text { Self-direction } \\
\text { Stimulation }\end{array}$ & $\begin{array}{l}\text { Offer challenges and variety at work, stimulating curiosity, } \\
\text { creativity and innovation }\end{array}$ \\
\hline Welfare & Hedonism & Promote satisfaction, welfare, and quality of life at work \\
\hline Achievement & Achievement & Value workers' competence and success \\
\hline Mastery & Power & Obtain profit, be competitive, and dominate the market \\
\hline Prestige & Power & $\begin{array}{l}\text { Gain status, be recognized and admired by everyone, offer } \\
\text { service and products that please clients }\end{array}$ \\
\hline Tradition & Tradition & Keep traditions and respect organizational customs \\
\hline Conformity & Conformity & $\begin{array}{l}\text { Promote correctness, courtesy, and desired behavior at } \\
\text { work, as well as respecting the organization's norms }\end{array}$ \\
\hline Collective & $\begin{array}{l}\text { Benevolence } \\
\text { Universalism }\end{array}$ & $\begin{array}{l}\text { Promote justice, equality, tolerance, frankness, and } \\
\text { honesty at the organization }\end{array}$ \\
\hline
\end{tabular}

Source: Adapted from Oliveira and Tamayo (2004).

According to Tamayo and Gondim (1996), understanding organizational values means to focus on the workers' point of view since they are linked to the organization and, therefore, their perceptions represent the organizational reality. Thus, individual perceptions constitute the core of the values shared by the organization's members, and they are able to reach the hierarchical periphery of axiological priority (NASCIMENTO, ADAID-CASTRO, CARVALHO et al., 2016). Following the same path as the model by Oliveira and Tamayo (2004), the theoretical lens adopted in this study is supported by individual perceptions in order to analyze organizational values.

\section{Performance at work}

There is consensus in the literature that the concept of performance encompasses aspects of behavior and results (CAMPBELL, 1990; SONNENTAG and FRESE, 2002). The behavioral dimension refers to what the individual does while working, whereas 'result' refers to the consequence of the individual behavior (FOGAÇA, REGO, MELO et al., 2018). Task performance is one of the general dimensions of work performance and usually appears in seminal studies on workers' assessment. However, only recently has the role of relational aspects gained space in research on performance (MACIEL and CAMARGO, 2016).

Campbell (1990) developed one of the classic models in the area of performance. The author structured the components of performance according to three major determinants: declarative knowledge, related to facts, principles, goals, interests, capabilities, and experience; procedural knowledge, linked to cognitive, psychomotor, and social skills necessary to perform the task; and motivation, which comprises the level of the individual's effort and their degree of persistence while performing.

For Campbell (1990), performance refers to the action per se, not only its consequence or result. Sonnentag and Frese (2002) followed the taxonomy proposed in the works led by Campbell (1990) and operationalize the construct, associating it with factors related to the individual (wanting to do), related to the task (knowing how to do), or related to the context (having the ability to do), dividing performance into two facets: task and contextual performance.

Task performance is multidimensional and encompasses five factors: 1) job-specific task proficiency; 2) non-job-specific task proficiency; 3) written and oral communication; 4) supervision; and 5) management/administration. According to Queiroga, Borges-Andrade and Coelho Junior (2015), task performance represents how the individual contributes to the technical aspects of the organization. It is based on the performance of their work activities, and the contribution may occur directly (focused on production) or indirectly (focused on management). 
Contextual performance, based on Sonnentag and Frase (2002), can be divided into two types: behaviors that essentially seek the smooth functioning of the organization; and the proactive behaviors aimed at changing and improving work and organizational processes. This research follows the model proposed by Queiroga, Borges-Andrade and Coelho Junior (2015), seeking to analyze the performance at work based on the task and contextual performance.

\section{METHODOLOGY}

This descriptive and explanatory research uses both quantitative (phase I) and qualitative (phase II) approaches.

The participant organizations are private companies operating in the retail sector, located in the malls established in the Southern Brazilian city of Santa Maria, State of Rio Grande do Sul. They were selected considering the multiplicity of organizational realities characteristic of the different companies operating in a shopping mall. This choice led to an explanatory analysis of how the constructs researched presented and relate to each other, considering the different contexts of each researched organization. The research observed the businesses that met the established criteria, located in four shopping malls in the city. The common characteristics of the participating organizations are: I-operating in the retail sector; II -located in the shopping malls selected by researchers; III -a work team with at least four employees; and IV - agreed to be part of the study.

In phase I, the population was made up of the absolute sum of all employees of the participating organizations. The research used the software G*Power 3 for statistical power analysis and SmartPLS for estimation using structural equation modeling (SEM) data analysis technique. Following parameters suggested by Hair Junior, Hult, Ringle et al. (2013), the study adopted a significance level of $5 \%$, the statistical power of $80 \%$, and an effect size (f2) of $15 \%$. The sample counted on 260 participants responding to valid questionnaires, which is more than the minimum of 85 participants required in research works adopting similar parameters. The questionnaires were applied in person, from September to November 2016.

The questionnaire used in this phase was designed in four parts. The first part collected personal and occupational data. The second part obtained information on organizational linkages related to commitment (BASTOS and AGUIAR, 2015), entrenchment (RODRIGUES and BASTOS, 2015), and consent (SILVA and BASTOS, 2015). Part three collected data on organizational values (OLIVEIRA and TAMAYO, 2004), and the fourth and last part was designed to get data related to performance at work (QUEIROGA, BORGES-ANDRADE and COELHO JUNIOR, 2015).

After an initial confirmatory factor analysis conducted on the measurement scales, tests were carried out to learn the influence among the constructs. The SEM technique was applied based on estimating models of partial least squares fit using the software SmartPLS, based on the sequence proposed by Rigle, Silva and Bido (2014). In this phase, variables that had low factor loading and did not fit the proposed model were excluded.

Based on the literature and seeking to explain in detail the theoretical foundations justifying the relationships between the constructs, the following hypotheses were elaborated:

- $\quad \mathbf{H 1}$ - Workers who share values where the motivational types of 'self-transcendence' (collectivity) and 'openness to change' (autonomy and welfare) are stronger than other motivational types, usually establish a linkage of organizational commitment.

- $\quad \mathbf{H 2}$ - Workers who share values where the motivational types of 'self-enhancement' (welfare, achievement, and mastery) and 'conservation' (tradition and conformity) are stronger than other motivational types, usually establish a linkage of organizational entrenchment.

- $\quad$ H3 - Workers who share values where the motivational types of 'conservation' (tradition and conformity) are stronger than other motivational types, usually establish a linkage of organizational consent.

- $\quad$ H4 - Workers who establish linkages where organizational commitment is stronger than other linkages present better work performance.

- $\quad$ H5 - Workers who establish linkages where organizational entrenchment and consent are stronger than the linkage of organizational commitment present worse work performance. 
In phase II, interviews were conducted with managers of the participant organizations. The selection of interviewees was carried out after the preliminary results obtained in phase $\mathrm{I}$. The participants were managers of organizations that presented higher levels of organizational ties, measured by calculating the mean for results obtained in phase I in the three constructs (commitment, entrenchment, and consent). The number of interviews was limited by the criterion of theoretical saturation, resulting in 10 managers interviewed. The interviews were carried out in person in January 2017. The interview script was developed based on thirty cards with statements that reflect the conceptual characteristics of the organizational linkages, developed by Pinho (2009). Based on these cards, the interviewees were asked to establish associations with organizational values (OLIVIERA and TAMAYO, 2004) and work performance (QUEIROGA, BORGES-ANDRADE and COELHO JUNIOR, 2015).

The data collected in the interviews were submitted to content analysis (BARDIN, 2011). The main categories of analysis were defined a priori, mirroring the theoretical models adopted. However, the research considered the possibility of changing the categories according to inputs from the interviews. The categories were treated considering the notions regarding antecedents and consequences of linkage employee-organization, focusing on associations of the linkages with organizational values and work performance.

\section{RESULTS AND DISCUSSION}

The results were organized into two sections according to the phases of the research.

\section{Phase I - Structural equation modeling}

Firstly, the measurement model was analyzed in order to test the influences among the constructs. Table 1 shows the values found for Cronbach's alpha indicators and average variance extracted (AVE), which guarantees the convergent validity and reliability of the measurement model.

Table 1

Convergent validity and reliability of the model fit

\begin{tabular}{l|c|c}
\hline \multicolumn{1}{c|}{ Constructs } & Cronbach's Alpha & AVE \\
\hline Commitment & 0.911 & 0.507 \\
\hline Entrenchment - Adjustment to social position & 0.764 & 0.515 \\
\hline Entrenchment - Impersonal bureaucratic arrangements & 0.702 & 0.526 \\
\hline Entrenchment - Limited alternatives & 0.878 & 0.622 \\
\hline Consent & 0.857 & 0.584 \\
\hline Value - Autonomy & 0.752 & 0.503 \\
\hline Value - Welfare & 0.799 & 0.501 \\
\hline Value - Conformity & 0.695 & 0.522 \\
\hline Value - Mastery & 0.720 & 0.542 \\
\hline Value - Collectivity & 0.874 & 0.570 \\
\hline Value - Prestige & 0.762 & 0.584 \\
\hline Value - Achievement & 0.788 & 0.611 \\
\hline Value - Tradition & 0.762 & 0.677 \\
\hline Contextual performance & 0.892 & 0.571 \\
\hline Task performance & 0.864 & 0.596 \\
\hline
\end{tabular}

Source: Elaborated by the authors.

The reliability indicators present satisfactory values with Cronbach's alpha above 0.7 (HAIR JUNIOR, HULT, RINGLE et al., 2013). As for the convergent validities, AVE higher than 0.5 indicated that the model converges to a satisfactory result.

Two criteria were used to observe the discriminant validity. The first one was proposed by Fornell and Larcker (1981) and established that the square roots of the AVE must be greater than the correlations between the latent variables. The second is 
Chin's (1998) criterion, which verifies the cross-loadings. It states that the highest factor loading of each observed variable must be associated with its respective latent variable. The discriminant validity analysis of the measurement model met both criteria.

After completing the measurement model fitting process, the structural model was analyzed. In the analysis of the variance inflation factors (VIF), none of the latent variables had multicollinearity problems since all constructs presented VIF $<5$ (HAIR JUNIOR, HULT, RINGLE et al., 2013).

The indicators of model fit were assessed in this phase. The indicators were the predictive relevance or validity (Q2) or StoneGeisser's indicator, and effect size (f2) or Cohen's (1998) indicator. All the indicators met the criteria when observing the recommendation by Hair Junior, Hult, Ringle et al. (2013), with all indices greater than zero. As for the effect size (f2), the indices $0.02,0.15$, and 0.35 are considered small, medium, and large, respectively (HAIR JUNIOR, HULT, RINGLE et al., 2013). According to these parameters, the effect size of the latent variables in this study can be classified as high or moderate. The values of Q2 and $\mathrm{f} 2$ confirm, in general, that the model is accurate and that the constructs are important for the general model fitting. In order to finalize the analysis of the structural model, the general model fitting was evaluated using the goodness of fit index, proposed by Tenenhaus, Vinzi, Chatelin, et al. (2005). As the authors suggest 0.36 as a parameter, and the results showed an index of 0.417 , the model fits and was considered adequate.

Finally, it was necessary to verify whether the relationships of the structural model are significant $(p £ 0.05)$, applying the Student's t-test (Table 2).

Table 2

\section{Student's t-teste}

\begin{tabular}{|c|c|c|c|}
\hline Relationship & T-statistics & P-value & Conclusion \\
\hline Autonomy-> Commitment & 3.056 & 0.002 & Accept \\
\hline Autonomy-> Consent & 0.708 & 0.480 & Reject \\
\hline Autonomy-> Entrenchment & 1.114 & 0.266 & Reject \\
\hline Welfare-> Commitment & 4.278 & 0.000 & Accept \\
\hline Welfare-> Consent & 1.368 & 0.172 & Reject \\
\hline Welfare-> Entrenchment & 2.802 & 0.005 & Accept \\
\hline Conformity-> Commitment & 0.927 & 0.354 & Reject \\
\hline Conformity-> Consent & 2.231 & 0.026 & Accept \\
\hline Conformity-> Entrenchment & 0.440 & 0.660 & Reject \\
\hline Mastery-> Commitment & 3.432 & 0.001 & Accept \\
\hline Mastery-> Consent & 0.705 & 0.481 & Reject \\
\hline Mastery-> Entrenchment & 1.078 & 0.281 & Reject \\
\hline Collectivity-> Commitment & 3.625 & 0.000 & Accept \\
\hline Collectivity-> Consent & 0.614 & 0.540 & Reject \\
\hline Collectivity-> Entrenchment & 1.091 & 0.276 & Reject \\
\hline Prestige-> Commitment & 1.281 & 0.201 & Reject \\
\hline Prestige-> Consent & 0.307 & 0.759 & Reject \\
\hline Prestige-> Entrenchment & 0.164 & 0.869 & Reject \\
\hline Achievement-> Commitment & 1.263 & 0.207 & Reject \\
\hline Achievement-> Consent & 2.643 & 0.008 & Accept \\
\hline Achievement-> Entrenchment & 0.512 & 0.609 & Reject \\
\hline Tradition-> Commitment & 1.086 & 0.278 & Reject \\
\hline Tradition-> Consent & 0.875 & 0.382 & Reject \\
\hline Tradition-> Entrenchment & 0.228 & 0.820 & Reject \\
\hline Commitment-> Work performance & 6.807 & 0.000 & Accept \\
\hline Consent-> Work performance & 2.236 & 0.026 & Accept \\
\hline Entrenchment-> Work performance & 1.202 & 0.230 & Reject \\
\hline
\end{tabular}

Source: Elaborated by the authors. 
The results of the analysis of significant relationships among the variables (Table 2) are systematized in Figure 1 that presents the path coefficients explaining the power of influence of one construct on the other and the coefficients of determination of the model relationships $\left(R^{2}\right)$, which show how much a construct is explained.

Figure 1

Structural model to test hypotheses

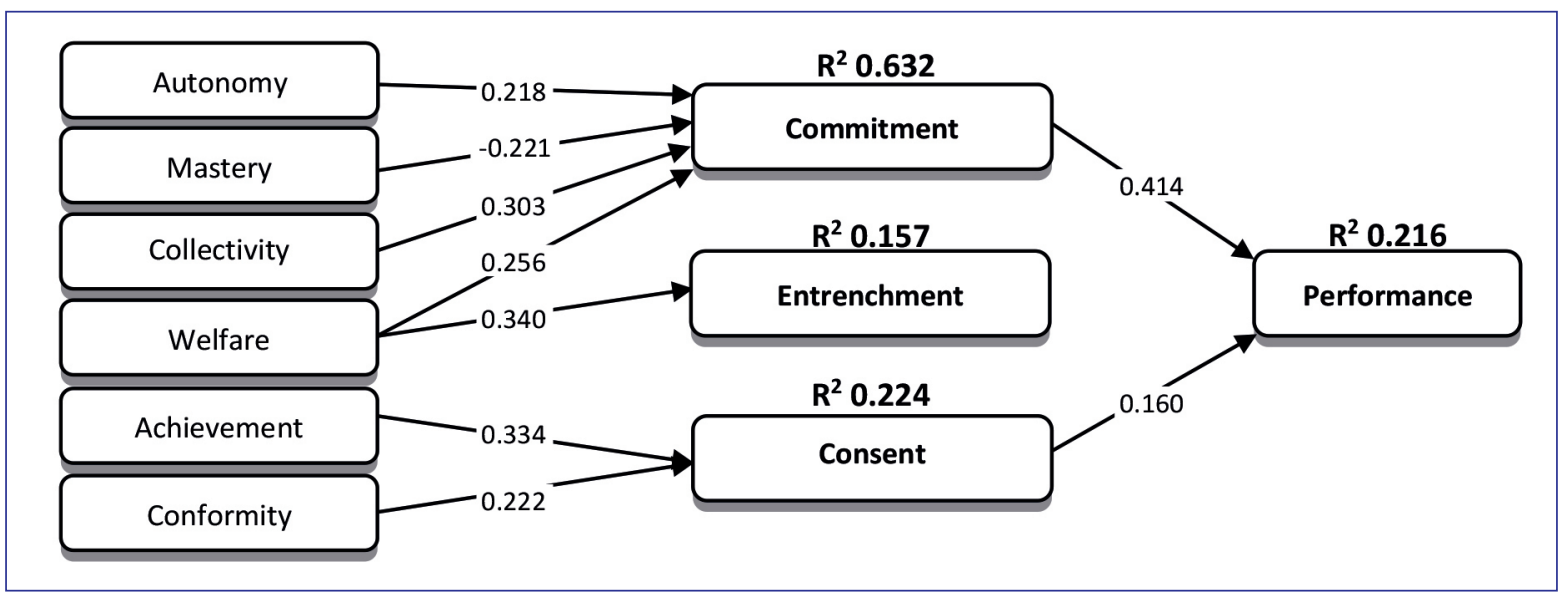

Source: Elaborated by the authors.

The data in Figure 1 shows that the coefficient of determination $\left(\mathrm{R}^{2}\right)$ identified for organizational commitment, indicates that the variance of the construct can be explained in $63.2 \%$, and its predictors are the values 'autonomy,' 'mastery,' 'collectivity,' and 'welfare.'

In the value 'collectivity' $(\beta=0.303)$, the importance attributed by the organization to fair and equal treatment in the relationship with its employees and with other parts close to the community (OLIVEIRA and TAMAYO, 2004) is evident. It seems correct to say that this organizational value is a predictor of commitment since its actions are linked to the promotion of a work environment that prioritizes the welfare of others - which is necessary for group life and the relationship of humanity with the physical and social means. It should be noted that this value presented the highest path coefficient, i.e., it is potentially the greatest determinant of the affective bond.

The value 'welfare' at work $(\beta=0.256)$, according to Oliveira and Tamayo (2004), refers to the values of the organization that aim to promote satisfaction, welfare, and quality of life at work, to create a pleasant work environment. Tamayo (2005) analyzed the organizational values that determine affective commitment, in which this value was also observed as a predictor of commitment. These goals seem compatible with the concept of organizational commitment, as they demonstrate the concern of the organization with the happiness of its members through the promotion of actions directly linked to the motivations, goals, and aspirations of the worker, which stimulates the commitment bond (TAMAYO, 2005).

The value 'autonomy' $(\beta=0.218)$ is characterized by organizational goals that prioritize challenge and variety at work, curiosity, creativity, and innovation (OLIVEIRA and TAMAYO, 2004). This organizational value also appears in the study by Tamayo (2005) as a predictor of affective commitment. For this author, the result is convergent with the theoretical perspectives that explain autonomy, since its content responds to the needs, motivations, and deep aspirations of the worker and any human being.

The value 'mastery' ( $\beta=-0.221$ ) presented a negative $\beta$ in the relationship with commitment linkage. This value expresses the organization's goals regarding profit, competitiveness, and dominating the market (OLIVEIRA and TAMAYO, 2004). Tamayo (2005) also observed a negative $\beta$ in his study, explaining the result by arguing that this value inhibits affective commitment and identification with the organization. For the author, this phenomenon may be associated with the fact that workers do not consider themselves as a participant in the organization's achievements. 
These results demonstrate that the axiological goals integrated with the values 'collectivity,' 'welfare,' and 'autonomy' favor the linkage of commitment, whereas 'mastery' is a value that makes it difficult. This perspective corroborates the study by Tamayo (2005) who found that commitment is antagonistic with values that focus on tradition and dominating the market, while the prestige of the organization and its products or services in society, as well as the importance given to employees' autonomy and welfare, favors the development of commitment linkages.

As for the linkage of entrenchment, the results show that the value 'welfare' is an antecedent of this bond, showing an explanatory power of $15.7 \%$ of the construct's variance. Furthermore, the path coefficient reveals that welfare has a degree of $34 \%$ ( $\beta=0.340$ ) of influence on the individual's entrenchment linkage with the organization. This value also had an influence on commitment. This result, at first, may seem difficult to understand. However, the focus of the value 'welfare' is on organizational goals related to developing a pleasant work environment, promoting satisfaction, and quality of life at work (TAMAYO, 2005). While this value is associated with the idea of the individual's happiness for working in the organization, it appears as a predictor of commitment. On the other hand, the individual's perception that the organization offers benefit packages and quality of life at work may represent an important factor in their decision to stay, as well as the loss of those benefits associated with their leaving.

Analyzing the linkage of consent, the model was able to explain $22.4 \%$ of the construct's variance, and the path coefficients show that consent is determined at $33.4 \%(\beta=0.334)$ by the value 'achievement' and $22,2 \%(\beta=0.222)$ by the value 'conformity.'

The first predictor, achievement, is characterized by the success as the central goal, obtained through the organization's competence, which also reflects on the employees, whether in their actions in the workplace or privately (TAMAYO, 2005). The consent linkage carries a strong call for obedience, representing a state of dependence and subservience (the subordinate is the dependent party). In the organizational context, this is reflected in the quick adherence to the standards by the individuals, who perceive the companies' appreciation toward their competence and believe in their role in the organization's success. It is in this relationship of dependence that the worker understands the individual success coupled with the success of the organization. This is when the employee becomes more willing to consent.

The second predictor of consent, the value 'conformity,' prioritizes aspects such as courtesy, good behavior at work, and respect for the organization's rules, seeking to control the behavior of the employees (OLIVEIRA and TAMAYO, 2004). Conformity is one of the fundamental elements of organizational stability, encompassing the company's efforts to guarantee that orders and rules are followed. In addition, the notion of conformity limits the employee's scope for action, often disqualifying their judgment and ability to act.

As a consequence of the model, work performance is predicted by commitment and consent, where these two organizational linkages explain $22.4 \%$ of the construct's variance. Given these data, it appears that commitment is characterized as the greatest predictor of performance $(\beta=0.414)$. This means that the individual with high levels of emotional attachment, who identifies with organizational values and gets involved with work roles, tends to perform their work activities successfully. This corroborates the finding by Mowday, Porter and Steers (1982) who explain that commitment, as an affective bond, represents something beyond the simple passive loyalty to an organization, involving a relationship of affection, in which the employee wants to put maximum effort into their work to contribute to the organization.

It is also observed that consent, despite being less relevant than commitment, represented a significant variable in the model to explain work performance $(\beta=0.160)$. Thus, due to a perception that the managers know what must be done, the employee's willingness to comply with orders, rules, or norms established by the organization, positively influences their work performance. Entrenchment, for instance, did not have a significant relationship with performance at work.

To systematize the discussion, Box 2 presents the conclusion regarding the hypotheses proposed. 


\section{Box 2}

\section{Evaluation of the research hypotheses}

\begin{tabular}{|c|l|c|}
\hline \multicolumn{1}{|c|}{ Hypothesis } & Conclusion \\
\hline H1 & $\begin{array}{l}\text { Workers who share values where the motivational types of 'self-transcendence' (collectivity) and } \\
\text { openness to change' (autonomy and welfare) are stronger than other motivational types, usually } \\
\text { establish a linkage of organizational commitment. }\end{array}$ & Confirmed \\
\hline H2 & $\begin{array}{l}\text { Workers who share values where the motivational types of 'self-enhancement' (welfare, } \\
\text { achievement, and mastery) and 'conservation' (tradition and conformity) are stronger than other } \\
\text { motivational types, usually establish a linkage of organizational entrenchment. }\end{array}$ & $\begin{array}{c}\text { Partially } \\
\text { confirmed }\end{array}$ \\
\hline H3 & $\begin{array}{l}\text { Workers who share values where the motivational types of 'conservation' (tradition and } \\
\text { conformity) are stronger than other motivational types, usually establish a linkage of } \\
\text { organizational consent. }\end{array}$ & Confirmed \\
\hline H4 & $\begin{array}{l}\text { Workers who establish linkages where organizational commitment is stronger than other linkages } \\
\text { present better work performance. }\end{array}$ & Confirmed \\
\hline H5 & $\begin{array}{l}\text { Workers who establish linkages where organizational entrenchment and consent are stronger } \\
\text { than the linkage of organizational commitment present worse work performance. }\end{array}$ & $\begin{array}{c}\text { Partially } \\
\text { confirmed }\end{array}$ \\
\hline
\end{tabular}

Source: Elaborated by the authors.

\section{Phase II - Interviews with managers}

Regarding the ten interviewees' personal and occupational profile, there were six women and four men, and their ages ranged from 21 to 55 years old. Six of the managers completed higher education, most of them in the management area. As for the length of service in the company, the time varies from 4 to 24 years, and the time in the managerial position varies between 1 and 15 years.

To deeply explore the hierarchy of values associated with the establishment of employee-organization bonds, the interviewees received thirty cards with statements that represented characteristics of the three organizational linkages (commitment, entrenchment, and consent). After naming each of the linkages based on their perceptions, the managers received eight other cards, referring to the organizational values, described according to the concepts of Oliveira and Tamayo (2004). The interviewee was asked to determine which type of organizational linkage each value was associated with. The managers' associations are systematized in Table 3.

Table 3

Associations between organizational linkages and values

\begin{tabular}{l|c|c|c}
\hline \multicolumn{1}{c|}{ Values } & Commitment & Entrenchment & Consent \\
\hline Autonomy & 10 & 0 & 0 \\
\hline Welfare & 7 & 3 & 4 \\
\hline Conformity & 3 & 3 & 5 \\
\hline Mastery & 5 & 0 & 0 \\
\hline Collectivity & 8 & 2 & 0 \\
\hline Prestige & 8 & 2 & 0 \\
\hline Achievement & 10 & 0 & 5 \\
\hline Tradition & 4 & 1 & 5 \\
\hline
\end{tabular}

Source: Elaborated by the authors. 
Table 3 shows that organizational values were more often associated with commitment. The managers' discourse also demonstrated this trend:

I'm going to put everyone in this first one here [commitment] [...] I think that insecure and passive people don't have much identification with the organization's values. In general, they only think of themselves (Interviewee \#5).

Because I think these values fit perfectly into this [commitment], the employee has to have their own achievement, they have to feel good working in the company [referring to welfare], [show] conformity, [have] prestige, and autonomy (Interviewee \#7).

When analyzing the discourse, it seems correct to say that the sharing of the organization's values is directly associated with the patterns of the established organizational linkages. However, the values associated with consent reveal that sharing the organization's values prioritizes aspects such as competitiveness and dominating the market, respecting the organization's rules and expected behavior, and maintaining traditions and customs (dimensions that are part of - or closer to - the dimension of conservation), tend to favor this type of organizational linkage.

Furthermore, associations with entrenchment suggest that the development of this bond is favored by values related to adherence to conventions, such as obedience and formality. The perception of these values seems to foster continuance or instrumental and diminish affective linkage, which may corroborate the association of entrenchment with the value 'conformity.'

Commitment has a configuration of the priority of values that is different from the hierarchy associated with the idea of entrenchment or consent. Being committed means that the individual identifies with the values shared within the organization. This identification involves acceptance, considering that there is a desire toward being affiliated with the organization. People adopt attitudes and behaviors due to the adjustment between their hierarchies of personal values and the values of the organization (MOWDAY, PORTER and STEERS, 1982).

In the second moment of the interview, managers were asked about what type of performance could be observed for individuals considered in each of the three linkages. The interviewees were asked to use their own terms to describe the performance (Figure 2).

Figure 2

Associations between organizational linkages and work performance

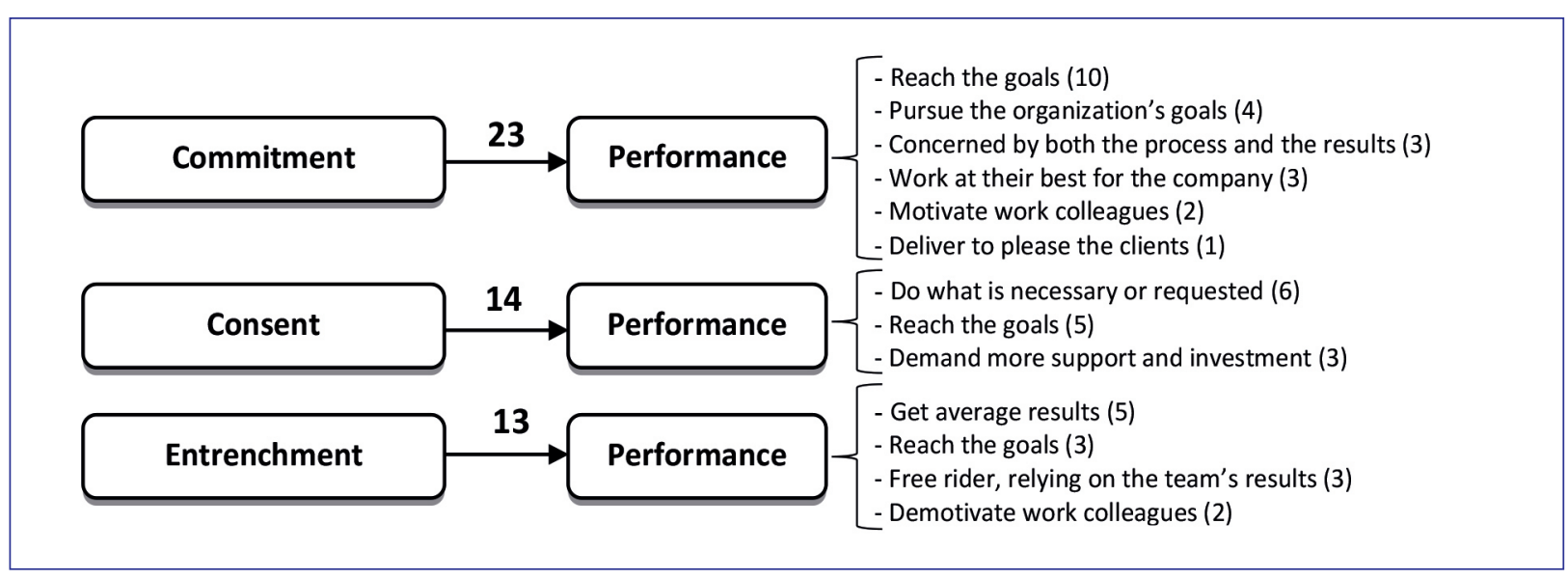

Source: Elaborated by the authors.

The interviewees attributed a more negative sense to work performance when related to the linkages of entrenchment and consent, different from the positive impression observed for commitment. A similar result was found by Pinho, Bastos 
and Rowe (2015a), where entrenchment and consent were considered as not favoring individual or organizational growth, jeopardizing the achievement of both parties' goals.

The interviewees' discourse revealed this positive sense attributed to commitment:

If there is an employee who is committed to the company, they even help you in management, talking to the customer, serving the customer better, they are concerned with the sales targets, if we were not reaching the goal they go there and motivate colleagues, they help you with everything (Interviewee \#1).

They are people who care about the piece of paper left on the floor, whether it is a recyclable paper to throw away or if it is still useful. This is the dream, I do not say it only as a manager, but this is the dream of any business person (Interviewee \#4).

In contrast, managers see entrenchment and consent in a very similar way, as types of bonds that bring little contribution to the organization:

Because the person who is most laid back, the person you will approach them, and they will be sitting in a corner, they will not be willing to help you, it is like putting an injured player in the game, they will not deliver in the same way [...] if you have rotten lemons on your team, everything is bad, and they end up making the job difficult, sometimes they don't do it and end up contaminating the others (Interviewee \#1).

Yes, the result is fatal for the company, here in these two [entrenchment and consent]. The moment one settles in, saying 'whatever,' this creates serious problems (Interviewee \#2).

These here [entrenchment and consent] they end up reaching the sales targets because if they don't reach it, they are out. But they are the person I need to be motivating all the time, calling them to work, reminding them what they have to do. They demand much more from me than this one [committed worker] (Interviewee \#7).

It appears that both linkage, entrenchment, and consent can be associated with the achievement of goals. However, the organization needs to put more effort and spend more to support workers in this kind of linkage. Thus, it is possible to say that the entrenched or consented worker's performance when reaching the productivity goals is a task performance, i.e., they contemplate localized and specific results of their work activities. Therefore, workers linked to the organization through entrenchment or consent are also productive if the goal considers their specific and technical performance in the operational tasks. This result reinforces the analysis by Klein, Molloy and Brinsfield (2012), who argue that, in addition to commitment, other types of bonds can be considered appropriate, observing the organization's context and objectives.

The committed individual goes beyond technical issues - as observed in the discourse of the managers interviewed. They put effort into more strategic issues, aware of details and factors that lead to achieving the organization's global objectives and goals, adopting a contextual performance. This finding corroborates Maciel and Camargo (2016), who explained that the psychological connection is important for individuals to reflect on the action related to a linkage, and that this reflection influences their performance. 


\section{FINAL CONSIDERATIONS}

This article develops a model that better explains how different individual-organization linkages resemble or differ regarding antecedents and consequents, bringing important contributions to scientific studies in the field of administration, especially on topics related to organizational behavior. The analytical model proposed in this study considers the inclusion of organizational values and work performance as antecedent and consequent variables of the bond between employee and organization, which allows future organizational interventions to diagnose with greater precision the types and combinations of such linkages.

An important contribution of the research was to identify that certain values shared by the organization are determinants of the type of employee-organization bonds, with different values influencing different bonds. As a consequence, it is possible to say that the type of organizational linkage influences the individual's work performance. The results found that commitment is the linkage with the greatest power to explain the construct 'work performance.' The narratives of the interviewed managers reinforce this finding, associating commitment to higher levels of productivity, motivation, and engagement at work. As for consent, however, the results presented a significant relationship, but the path coefficient was lower than the one observed for commitment, with a positive influence on work performance. Finally, the entrenchment showed no significant relationship. Future studies in this field should try repeating this model to verify consistency, as well as testing it in different contexts.

This research showed that entrenched and consenting workers are not unproductive. However, the nature of these linkages requires greater support from the organization and managers so that workers can successfully perform their activities. In general, the efforts of these individuals are focused on reaching individual goals and little contribution to the organization's more global performance objectives. This result supports the argument that the academic studies should develop a new look on the consequences of entrenchment and consent linkages, which - although not associated with high-performance can be considered necessary and desirable bonds in specific organizational contexts. This is even more important when one advocates that levels of these two linkages can be combined with levels of commitment, understanding that the linkages coexist and are not mutually exclusive.

Finally, the limits of this study include the fact that it is restricted to a specific context. It is important to stress that the study addresses behavioral aspects and uses attitudinal scales, which have a subjective and complex nature. In addition, crosssectional data were used in the research.

Therefore, future research should carry out longitudinal studies that allow monitoring both the establishment and the maintenance of the individual's linkage with the organization, exploring how organizational values influence both phenomena. Also, other indicators can be included in the model to enrich the understanding regarding work performance. 


\section{REFERENCES}

BALSAN, L. A. G. et al. A influência do comprometimento, do entrincheiramento e do suporte à transferência de treinamento sobre o impacto do treinamento no trabalho. Revista de Administração da UFSM, v. 10, n. 6, p. 976-989, 2017.

BARDIN, L. Análise de conteúdo. Lisboa: Ed. 70, 2011.

BASTOS, A. V. B.; AGUIAR, C. V. N. Comprometimento organizacional. In: PUENTE-PALACIOS, K.; PEIXOTO, A. L. A. (Org.). Ferramentas de diagnóstico para organizações e trabalho: um olhar a partir da psicologia. Porto Alegre: Artmed, 2015. p. 78-91.

BECKER, H. S. Notes on the concept of commitment. American Journal of Sociology, v. 66, n. 1, p. 32-40, 1960.

CAMERON, K. S.; BRIGHT, D.; CAZA, A. Exploring the relationships between organizational virtuousness and performance. American Behavioral Scientist, v. 47, n. 6, p. 766-790, 2004.

CAMPBELL, J. P. Modeling the performance prediction problem in industrial and organizational psychology. In: DUNNETTE, M. D.; HOUGH, L. M. (Ed.). Handbook of industrial and organizational psychology. Palo Alto: Consulting Psychology Press, 1990. p. 687-732.

CARSON, K. D.; BEDEIAN, A. G. Career commitment: construction of a measure and examination of its psychometric properties. Journal of Vocational Behavior, v. 44, n. 3, p. 237-262, 1994.

CHIN, W. W. The partial least squares approach for structural equation modeling. In: MARCOULIDES, G. A. (Ed.). Modern methods for business research. London: Lawrence Erlbaum Associates, 1998. p. 295-336.

COHEN, J. Statistical power analysis for the behavioral sciences. New York: Psychology Press, 1998.

FOGAÇA, N. et al. Job performance analysis: scientific studies in the main journals of management and psychology from 2006 to 2015. Performance Improvement Quarterly, v. 30, n. 4, p. 231-247, 2018.

FORNELL, C.; LARCKER, D. F. Evaluating structural equation models with unobservable variables and measurement error. Journal of Marketing Research, v. 18, n. 1, p. 39-50, 1981.

GAO-URHAHN, X.; BIEMANN, T.; JAROS, S. J. How affective commitment to the organization changes over time: a longitudinal analysis of the reciprocal relationships between affective organizational commitment and income. Journal of Organizational Behavior, v. 37, p. 515-536, 2016.

HAIR JUNIOR, J. F. et al. A primer on partial least squares structural equation modeling (PLS-SEM). Los Angeles: Sage, 2013.

HARTER, J. K. et al. Causal impact of employee work perceptions on the bottom line of organizations. Perspectives on Psychological Science, v. 5, n. 4, p. 378-389, 2010.

HEAVEY, A. L.; HOLWERDA, J. A.; HAUSKNECHT, J. P. Causes and consequences of collective turnover: a meta-analytic review. Journal of Applied Psychology, v. 98, n. 3, 412-453, 2010.

KLEIN, H. J. Commitment in organizational contexts: introduction to the special issue. Journal of Organizational Behavior, v. 37, p. 489-493, 2016.

KLEIN, H. J.; MOLLOY, J. C.; BRINSFIELD, C. T. Recconceptualizing workplace commitment to redress a stretched construct: revisiting assumptions and removing confounds. Academy of Management Review, v. 37, p. 130-151, 2012.

MACIEL, C. O.; CAMARGO, C. Social connection in organizations: the effects of local ties on job engagement and performance. Revista de Administração, v. 51, p. 377-385, 2016.

MAIA, L. G.; BASTOS, A. V. B.; SOLINGER, O. N. Which factors make the difference for explaining growth in newcomer organizational commitment? A latent growth modeling approach. Journal of Organizational Behavior, v. 37, n. 4, p. 537-357, 2016.

MEDEIROS, C. A. F.; AlbuQUeRQUE, L. G. Comprometimento organizacional: um estudo de suas relações com características organizacionais e desempenho nas empresas hoteleiras. Revista Psicologia: Organizações e Trabalho, v. 5, n. 1, p. 35-64, 2005.

MEYER, J. P.; ALLEN, N. J. A three-component conceptualization of organizational commitment. Human Resource Management Review, v. 1, n. 1, p. 61-89, 1991

MOWDAY, R. T.; PORTER, L. W.; STEERS, R. M. Employee-organization linkages: the psychology of commitment, absenteism and turnover. New York: Academic Press, 1982.

NASCIMENTO, T. G. et al. Valores organizacionais: uma análise bibliométrica da produção nacional do período de 2000 a 2013 na área de administração. Organizações em Contexto, v. 12, n. 24, p. 37-64, 2016.

OLIVEIRA, A. F.; TAMAYO, A. Inventário de perfis de valores organizacionais. Revista de Administração, v. 39, n. 2, p. 129-140, 2004.

PAIVA, K. C. M.; DUTRA, M. R. S. Valores organizacionais e valores do trabalho: um estudo com operadores de call center. Cadernos EBAPE.BR, Rio de Janeiro, v. 15, n. 1, p. 40-62, 2017.

PINHO, A. P. M. Comprometimento, entrincheiramento e consentimento organizacionais: uma análise destes vínculos, entre gestores e trabalhadores, de diferentes organizações. $256 \mathrm{f}$. Doctoral Dissertation (Doctor Degree in Administration) - Universidade Federal da Bahia, Salvador, 2009.

PINHO, A. P. M.; BASTOS, A. V. B.; ROWE, D. E. O. Diferentes vínculos indivíduo-organização: explorando seus significados entre gestores. Revista de Administração Contemporânea, v. 19, n. 3, p. 288-304, 2015a.

PINHO, A. P. M.; BASTOS, A. V. B.; ROWE, D. E. O. Diferentes vínculos organizacionais: explorando concepções, fatores organizacionais antecedentes e práticas de gestão. Organizações \& Sociedade, v. 22 , n. 75 , p. 659-680, 2015b.

QUEIROGA, F.; BORGES-ANDRADE, J. E.; COELHO JUNIOR, F. A. Desempenho no trabalho: escala de avaliação geral por meio de autopercepções. In: PUENTE-PALACIOS, K.; PEIXOTO, A. L. A. (Org.). Ferramentas de diagnóstico para organizações e trabalho: um olhar a partir da psicologia. Porto Alegre: Artmed, 2015. p. 36-45.

RINGLE, C. M.; SILVA, D.; BIDO, D. Modelagem de equações estruturais com utilização do SmartPLS. Revista Brasileira de Marketing, v. 3, n. 2, p. 54-71, 2014. 
RODRIGUES, A. C. A.; BASTOS, A. V. B. Entrincheiramento organizacional: construção e validação da escala. Psicologia: Reflexão e Crítica, v. 25 , n. 4 , p. 688-700, 2012.

RODRIGUES, A. C. A.; BASTOS, A. V. B. Entrincheiramento organizacional. In: PUENTE-PALACIOS, K.; PEIXOTO, A. L. A. (Org.). Ferramentas de diagnóstico para organizações e trabalho: um olhar a partir da psicologia. Porto Alegre: Artmed, 2015. p. 107-120.

SCHEIBLE, A. C. F.; BASTOS, A. V. B. An examination of human resource management practices influence on organizational commitment and entrenchment. Brazilian Administration Review, v. 10, n. 1, p. 57-76, 2013.

SCHWARTZ, S. H. Universals in the content and structure of values: theoretical advances and empirical tests in 20 countries. In: ZANNA, M. (Org.). Advances in experimental social psychology. San Diego: Academic Press, 1992. p. 1-65.
SILVA, E. E. C.; BASTOS, A. V. B. Consentimento organizacional. In PUENTE-PALACIOS, K.; PEIXOTO, A. L. A. (Org.). Ferramentas de diagnóstico para organizações e trabalho: um olhar a partir da psicologia. Porto Alegre: Artmed, 2015. p. 92-106.

SONNENTAG, S.; FRESE, M. Performance concepts and performance theory. In: SONNENTAG, S. (Ed.). Psychology management of individual performance. Oxford: John Wiley \& Sons, 2002. p. 3-27.

TAMAYO, A. Valores organizacionais e comprometimento afetivo. Revista de Administração Mackenzie, v. 6, n. 3, p. 192-213, 2005.

TAMAYO, A.; GONDIM, M. G. C. Escala de valores organizacionais. Revista de Administração, v. 31, n. 2, p. 62-72, 1996.

TENENHAUS, M. et al. PLS path modeling. Computational Statistics \& Data Analysis, v. 48, n. 1, p. 159-205, 2005. 